\title{
ADSORPSI PENCEMARAN LIMBAH CAIR INDUSTRI PENYAMAKAN KULIT OLEH KITOSAN YANG MELAPISI ARANG AKTIF TEMPURUNG KELAPA
}

\author{
Musrowati Lasindrang \\ Program Studi Ilmu Lingkungan Sekolah Pascasarjana \\ Universitas Gadjah Mada \\ Email: Atik. environmentalscience@gmail.com
Suwarno, Hadisusanto, dan Salahudin Djalal Tandjung
Jurusan Biologi Fakultas MIPA
Universitas Gadjah Mada \\ Kamiso Handoyo Nitisastro \\ Jurusan Perikanan Fakultas Pertanian \\ Universitas Gadjah Mada
}

\begin{abstract}
Chitosan has been used as biosorbent. In addition to having advantage chitosan as biosorbent has also disadvantage. Chitosan is very soluble in low $\mathrm{pH}$ so it cannot adsorb $\mathrm{Cr}$ (total) atlow $\mathrm{pH}$. It is due to active site (amine group) of chitosan undergo protonation and its adsorption capability is easily influenced by anions in waters. Therefore, the research studied use of chitosan coating active charcoal of coconut shell to increase adsorption capability of $\mathrm{Cr}$ (total), BOD, COD. This research was done to evaluate characteristic of liquid waste quality with Wastewater treatment unit (IPAL) or without Wastewater treatment unit (IPAL) and compare with Regulation of DIY Governor number 7/2010. It studied also effect of $p H$ and Concentration of chitosan coating active charcoal as adsorbent on decrease in $\mathrm{Cr}$ (total), BOD, and COD concentration on liquid waste of leather tanning. The results indicate liquid waste of leather tanning industry with Wastewater treatment unit (IPAL) and without Wastewater treatment unit (IPAL) have exceeded quality standard of liquid waste of leather tanning industry. ANOVA statistical test indicated $\mathrm{Cr}$ (total), BOD, COD are significant at $0,05(p<0,05)$, various $p H$ influenced decrease in $\mathrm{Cr}$ (total), BOD, COD. The highest removal percentage on effect of chitosan concentration coating active charcoal is obtained in adsorbent C (K3A1), Cr (total) $(91,9 \%) ; B O D(99,5 \%) ; C O D(98,47 \%)$
\end{abstract}

Keywords: Adsorption, Chitosan, $\mathrm{Cr}$ (total), BOD, COD.

\section{ABSTRAK}

Penggunaan kitosan sebagai biosorben telah banyak dilakukan. Di samping memiliki beberapa kelebihan, kitosan sebagai biosorben juga memiliki kekurangan. Kitosan mudah larut pada $\mathrm{pH}$ rendah sehingga tidak mampu mengadsorpsi logam $\mathrm{Cr}$ (total) pada $\mathrm{pH}$ rendah. Hal ini disebabkan situs aktif (gugus amina) dari kitosan mengalami protonasi dan kemampuan adsorpsinya mudah dipengaruhi oleh ion- 
ion dalam perairan. Untuk itu dalam penelitian ini diteliti penggunaan Kitosan yang melapisi arang aktif tempurung kelapa untuk meningkatkan kemampuan adsorpsi $\mathrm{Cr}$ (total), BOD, COD. Penelitian ini dilakukan untuk: mengevaluasi karakteristik parameter kualitas limbah cair dengan Instalasi Pengolahan Air Limbah (IPAL), maupun tanpa Instalasi Pengolahan Air Limbah (IPAL) dan dibandingkan dengan Peraturan Gubernur DIY No 7 Tahun 2010; Menganalisa pengaruhi $\mathrm{pH}$ dan konsentrasi kitosan yang melapisi arang aktif sebagai adsorben terhadap efisiensi penurunan kandungan $\mathrm{Cr}$ (total), BOD, COD, pada limbah cair penyamakan kulit. Berdasarkan hasil penelitian menunjukkan limbah cair industri penyamakan kulit baik dengan Instalasi Pengolahan Air Limbah (IPAL) maupun tanpa Instalasi Pengolahan Air Limbah (IPAL) telah melampaui Baku Mutu limbah cair industri penyamakan kulit; uji statistik Anova menunjukkan variabel $\mathrm{Cr}$ (total), BOD, COD, signifikan pada $0,05(\mathrm{p}<0,05)$, maka variasi $\mathrm{pH}$ berpengaruh terhadap penurunan $\mathrm{Cr}$ (total), BOD, COD. Persen removal tertinggi pada pengaruh konsentrasi kitosan yang melapisi arang aktif diperoleh pada Adsorben C (K3A1) sebesar 91,9\% $\mathrm{Cr}$ (total); 99,5\% BOD, dan 98,47\% COD.

Kata Kunci: Adsorpsi, Kitosan, Cr (total), BOD, COD.

\section{PENGANTAR}

Limbah cair industri penyamakan kulit merupakan salah satu masalah yang utama selama industri penyamakan kulit berlangsung karena menghasilkan bahan organik dan krom. Pencemaran limbah cair industri penyamakan kulit paling luas dampaknya karena proses pengerjaannya menggunakan air dalam jumlah yang banyak dan menghasilkan limbah yang dibuang langsung ke sungai, sehingga mempengaruhi kesehatan manusia serta dapat menimbulkan kematian biota perairan. Limbah industri penyamakan kulit merupakan masalah serius diantara limbah pencemar industri lainnya karena merupakan campuran yang kompleks dengan komposisi yang sulit diketahui secara tepat (Jost, 1990). Limbah industri kulit berubah-ubah dan berbeda- beda dari waktu kewaktu, sesuai dengan macam dan jumlah kulit mentah yang diproses, macam kulit jadi, jenis, dan jumlah bahan kimia yang ditambahkan, dan tingkat teknologi yang diterapkan. Terjadinya pencemaran lingkungan perairan oleh limbah penyamakan kulit dapat diketahui dengan cepat dari perubahan warna, bau, dan kejernihan.

Limbah industri penyamakan kulit dapat menyebabkan perubahan fisik dan kimia lingkungan yang menerima aliran limbah. Pencemaran yang terjadi antara lain disebabkan oleh bahan-bahan kimia yang digunakan dalam tahapan-tahapan proses yang tidak diserap dengan sempurna oleh kulit yang diolah, sehingga limbah yang timbul pada proses basah masih mengandung sisa-sisa bahan kimia dalam jumlah yang cukup besar, termasuk unsur logam. Salah satu logam yang berbahaya adalah krom. Krom dalam lingkungan perairan dengan konsentrasi tertentu dapat menimbulkan masalah. $\mathrm{Cr}$ (VI) dalam perairan mempunyai kelarutan yang tinggi dan bersifat toksik, korosif serta karsinogenik karena dapat menimbulkan kanker paru-paru bila terakumulasi dalam tubuhdan diperkirakan membentuk kompleks makro molekul dalam sel (Palar, 2008) Struktur kimia $\mathrm{CrO}_{4}{ }^{2-}$ memiliki kemiripan dengan $\mathrm{SO}_{4}{ }^{2-}$ sebagai ion nutrisi dalam sistem biologi. Hal ini menyebabkan $\mathrm{CrO}_{4}^{2-}$ dapat menembus membran sel dan dengan cepat mengalami reduksi (Ohtake dan Silver, 1994). Menurut Kaim dan Schwerderski (1994) bahwa ion $\mathrm{CrO}_{4}^{2-}$ dapat menembus inti sel dan menyerang protein atau DNA yang menyebabkan lepasnya rantai DNA, kesalahan replikasi DNA, dan mutasi gen pada organisme. Sebaliknya $\mathrm{Cr}$ (III) kurang toksik dibanding Cr (VI), tidak korosif tetapi juga memiliki sifat mutagenik bahkan karsinogenik. Keberadaan $\mathrm{Cr}$ (III) dalam tubuh dapat menyebabkan kanker paru-paru. Akumulasi krom yang melebihi konsentrasi yang dibutuhkan oleh tubuh dapat menyebabkan kematian. Mengingat 
ancaman yang demikian besar dari pencemaran limbah cair penyamakan kulit, maka upaya untuk mengatasi cemaran logam berat telah banyak dilakukan. Upaya tersebut dengan jalan mengurangi konsentrasi logam berat yang dibuang ke sungai, tetapi upaya tersebut sering tidak efektif dan dalam jangka waktu yang lama cemaran logam berat dapat merusak lingkungan karena proses akumulasi logam berat yang tidak seimbang dengan kemampuan swapentahiran dari lingkungan itu sendiri.

Salah satu upaya untuk mengatasi pencemaran disebabkan oleh industri penyamakan kulit adalah dengan cara menghilangkan krom dan bahan organik dari limbah cair industri penyamakan kulit yang murah dan alami misalnya dengan adsorpsi menggunakan adsorben yang berbasis sumber alam atau limbah yaitu dengan kitosan dan arang aktif tempurung kelapa. Menurut Griffon et al, 2006 menyatakan bahwa kitosan merupakan polimer kationik yang bersifat nontoksik, dapatmengalamibiodegradasidan biokompatibel. Metode adsorpsi umumnya didasarkan pada interaksi logam dengan gugus fungsional yang ada pada permukaan adsorben melalui interaksi pembentukan kompleks. Kitosan adalah biosorben bahan pencemar yang efektif karena Derajat Deasetilasi yang tinggi dan memiliki gugus amino bebas yang dikandungnya, sehingga bersifat polikationik yang mempunyai kemampuan untuk mengikat logam, protein dan zat warna (Zakaria et al, 2002). Selain memiliki beberapa kelebihan, kitosan juga memiliki kekurangan. Penggunaan kitosan sebagai biosorben telah banyak digunakan tetapi mempunyai kelemahan yaitu kitosan mudah larut pada $\mathrm{pH}$ rendah sehingga tidak mampu untuk mengadsorpsi logam $\mathrm{Cr}$ (III) pada keadaan $\mathrm{pH}$ rendah (Onar dan Sarisik, 2002). Hal ini disebabkan situs aktif (gugus amina) dari kitosan mengalami protonasi dan kemampuan adsorpsinya mudah dipengaruhi oleh anion-anion dalam perairan, sebaliknya arang aktif tempurung kelapa atau sering juga disebut karbon aktif adalah jenis karbon yang memiliki luas permukaan yang besar $\left(500 \mathrm{~m}^{2} / \mathrm{g}\right)$ (APCC, 2007) dan mempunyai daya serap tinggi karena mempunyai situs aktif yang dapat menyerap bahan-bahan organik maupun anorganik sehingga digunakan sebagai substrat untuk menempelkan kitosan agar dapat menyerap logam berat dan bahanbahan organik dari limbah cair industri lebih efektif. Hal ini sesuai dengan Rodrigues dan Reinoso (1998) yang menyatakan bahwa arang aktif adalah spesies dengan karakter amfoterik yaitu dapat bermuatan negatif atau positif dan tergantung pada $\mathrm{pH}$ larutan untuk menyerap bahan-bahan organik maupun anorganik. Adsorpsi anionik akan suka pada $\mathrm{pH}$ rendah dan sebaliknya untuk spesies kationik akan menyukai $\mathrm{pH}$ tinggi. Karena kegunaannya juga untuk menyerap logam berat makanya digunakan sebagai substratnya kitosan dalam menyerap logam berat pada industri penyamakan kulit. Adapun Tujuan Penelitian: Mengevaluasi karakteristik parameter kualitas limbah cair dengan Instalasi Pengolahan Air Limbah (IPAL) maupun tanpa Instalasi Pengolahan Air Limbah (IPAL) dan dibandingkan dengan Peraturan Gubernur DIY Nomor 7 Tahun 2010; Menganalisa Pengaruh pH dan konsentrasi Kitosan yang melapisi arang aktif sebagai adsorben terhadap efisiensi penurunan kandungan logam berat (Cr total), BOD, COD, pada limbah cair penyamakan kulit.

Penelitian ini dilakukan dengan metode pengambilan sampel untuk limbah cair menggunakan teknik Stratified Random Sampling dengan mempertimbangkan bahwa kegiatan yang dikaji memiliki karakteristik yang berbeda yaitu limbah cair yang menggunakan Instalasi Pengolahan Air Limbah (IPAL) dan limbah cair tanpa Instalasi Pengolahan Air Limbah (IPAL). Pengamatan limbah cair industri penyamakan kulit dilakukan di laboratorium, untuk mengetahui kandungan $\mathrm{Cr}$ (total), BOD, COD, dan 
dilanjutkan dengan menguji daya adsorpsi dari kitosan yang melapisi arang aktif.

\section{Pengambilan Sampel Limbah Cair Industri Penyamakan Kulit.}

Sampel limbah cair penyamakan kulit diambil pada saluran pembuangan limbah yang tidak menggunakan Instalasi Pengolahan Air Limbah (IPAL) dan menggunakan Instalasi Pengolahan Air Limbah (IPAL) serta dianalisa di Laboratorium meliputi: Suhu, pH, BOD, COD, Cr (total), TSS, dan Minyak/Lemak serta dibandingkan dengan Baku Mutu Limbah Cair Peraturan Gubernur DIY Nomor 7 Tahun 2010.

\section{Pembuatan Kitosan yang Melapisi Arang Aktif Tempurung Kelapa.}

Pembuatan Kitosan yang melapisi arang aktif mengacu seperti yang dilakukan oleh Nomanbhay dan Palanisamy. Sebanyak $15 \mathrm{~g}$ Arang aktif dimasukkan kedalam $15 \mathrm{ml}$ gel kitosan 1\% (1 g kitosandalam 100ml asam oksalat $10 \%$ ) dan campuran dikocok dengan shaker selama 24 jam. Perbandingan $15 \mathrm{ml}$ gel kitosan 1\% : $15 \mathrm{~g}$ Arang aktif dianggap 1:1 yang diberi kode (K1A1) (Nomanbhay dan Palanisamy, 2005). Campuran kemudian disaring, dicuci dengan aquades, dan dikeringkan. Proses pelapisan diulang sebanyak 3 kali untuk memperoleh kitosan yang tebal pada arang aktif. Arang aktif hasil pelapisan dengan kitosan dipisahkan dari larutan dan direndam dalam larutan $\mathrm{NaOH}$ 0,5\% selama 3 Jam untuk penetralan kemudian dilakukan penyaringan dan pencucian dengan aquades hingga diperoleh substrat yang netral. Arang aktif hasil pelapisan dikeringkan pada suhu $60^{\circ} \mathrm{C}$ hingga kering dan diperoleh berat yang konstan. Dengan prosedur yang sama juga dilakukan untuk $15 \mathrm{ml}$ gel kitosan 2\% : $15 \mathrm{~g}$ arang aktif dengan perbandingan 2:1 (K2A1) dan $15 \mathrm{ml}$ gel kitosan $3 \%: 15 \mathrm{ml}$ arang aktif.

\section{Uji Pengaruh pH dan Konsentrasi Kitosan yang Melapisi Arang Aktif Tempurung Kelapa terhadap Adsorpsi Cr (total), BOD, COD}

Sampel industri penyamakan kulit diambil sebanyak $25 \mathrm{ml}$, dipipet, dan dimasukkan ke dalam erlenmeyer 500 ml. pH larutan di dalam masing-masing erlenmeyer diatur dengan menambahkan larutan $\mathrm{HCl}$ $0,1 \mathrm{M}$ dan $\mathrm{NaOH} 0,1 \mathrm{M}$. Variasi $\mathrm{pH}$ yang digunakan adalah $\mathrm{pH}$ 1, 2,3, 4, 5, 6, dan pH 7. Kedalam setiap larutan dimasukkan 5 gr adsorben. Lakukan pengocokan dengan shaker selama 24 jam. Larutan yang diperoleh disaring dan filtrat yang diperoleh dianalisis dengan Spektrofotometer Serapan Atom, untuk mengetahui jumlah $\mathrm{Cr}$ (total), dan menganalisa BOD, COD yang tersisa dalam larutan setelah interaksi dengan adsorben.

\section{PEMBAHASAN \\ Hasil Analisis Kualitas Limbah Cair Penyamakan Kulit.}

Hasil analisis pengambilan sampel limbah cair penyamakan kulit tanpa Instalasi Pengolahan Air Limbah (IPAL) dan pengambilan sampel limbah cair penyamakan kulit dengan Instalasi Pengolahan Air Limbah (IPAL) untuk berbagai parameter fisika dan kimia disajikan pada Tabel 1 dan Tabel 2.

Tabel 1. Hasil Analisis sampel Limbah Cair Penyamakan Kulit Tanpa IPAL

\begin{tabular}{l|l|l|l|l}
\hline No & Paramater & Satuan & \multicolumn{1}{|c}{ Hasil Uji } & Baku Mutu Limbah Cair Provinsi DIY no 7 tahun 2010 \\
\hline 1 & pH & - & 3 & $6,0-9,0$ \\
\hline 2 & Suhu & ${ }^{\circ} \mathrm{C}$ & 25,5 & $\pm 3{ }^{\circ} \mathrm{C}$ \\
\hline 3 & DHL & $\mu \mathrm{mhos}$ & 920.00 & - \\
\hline 4 & BOD & $\mathrm{mg} / \mathrm{L}$ & $1.200,1$ & 40 \\
\hline 5 & COD & $\mathrm{mg} / \mathrm{L}$ & 3900 & 90 \\
\hline 6 & TSS & $\mathrm{mg} / \mathrm{L}$ & 640 & 40 \\
\hline
\end{tabular}




\begin{tabular}{l|l|l|l|l}
\hline No & Paramater & Satuan & Hasil Uji & Baku Mutu Limbah Cair Provinsi DIY no 7 tahun 2010 \\
\hline 7 & $\mathrm{Cr}$ & $\mathrm{mg} / \mathrm{L}$ & 644,850 & 0,4 \\
\hline
\end{tabular}

Tabel 2. Hasil Analisis Limbah Cair Penyamakan Kulit dengan IPAL

\begin{tabular}{l|l|l|l|l}
\hline No & Paramater & Satuan & \multicolumn{1}{|c}{ HasilUji } & Baku MutuLimbahCairProvinsi DIY no 7 tahun 2010 \\
\hline 1 & $\mathrm{pH}$ & - & 7,28 & $6,0-9,0$ \\
\hline 2 & Suhu & ${ }^{\circ} \mathrm{C}$ & 30,6 & $\pm 3{ }^{\circ} \mathrm{C}$ \\
\hline 3 & DHL & $\mu \mathrm{mhos}$ & 550 & - \\
\hline 4 & BOD & $\mathrm{mg} / \mathrm{L}$ & 128 & 40 \\
\hline 5 & COD & $\mathrm{mg} / \mathrm{L}$ & 114,608 & 90 \\
\hline 6 & TSS & $\mathrm{mg} / \mathrm{L}$ & 105 & 40 \\
\hline 7 & Cr & $\mathrm{mg} / \mathrm{L}$ & 0,5 & 0,4 \\
\hline
\end{tabular}

Berdasarkan Tabel 1 dan Tabel 2 diatas dikemukakan pembahasan yangberkaitan dengan parameter fisikadan parameterkimia.

\section{Temperatur.}

Pengukuran temperatur limbah cair sangat diperlukan untuk pengamatan aktivitas-aktivitas biologi, kimiawi, tingkat kelarutan, dan kejenuhan oksigen serta proses pembusukan. Aktivitas biologis serta reaksireaksi kimia akan meningkat dua kali lipat setiap kenaikan temperatur $10^{\circ} \mathrm{C}$, tingkat oksidasi bahan organik jauh lebih tinggi pada temperatur yang relatif tinggi dibandingkan pada temperatur yang rendah. Peningkatan temperatur ini disertai dengan penurunan kadar oksigen terlarut, sehingga tidak mampu memenuhi kebutuhan oksigen bagi organisme perairan untuk melakukan proses metabolisme dan respirasi (Effendi, 2003). Dari hasil analisis limbah cair penyamakan kulit tanpa Instalasi Pengolahan Air Limbah (IPAL), temperatur limbah nilainya $25,5^{\circ} \mathrm{C}$, dan limbah cair penyamakan kulit dengan Instalasi Pengolahan Air Limbah (IPAL) temperaturnya sebesar 30,6 ${ }^{\circ} \mathrm{C}$, masih dianggap normal untuk kehidupan aquatik jika limbah cair dengan Instalasi Pengolahan Air Limbah(IPAL) dibuang ke badan air atau sungai. Menurut Baku Mutu Limbah Cair provinsi DIY No 7 Tahun 2010 temperatur limbah cair masih sesuai dengan baku mutu.

\section{Derajat Keasaman (pH).}

Derajat keasaman $(\mathrm{pH})$ menunjukkan kadar asam atau basa dalam suatu larutan melalui konsentrasi atau aktivitas ion $\mathrm{H}^{+}$. $\mathrm{pH}$ merupakan suatu parameter fisik penting dalam pengendalian limbah cair. Karena banyak reaksi-reaksi kimia dan biologis yang melibatkan mikroorganisme berlangsung dalam $\mathrm{pH}$ tertentu. Apabila $\mathrm{pH}$ air sungai mengalami perubahan yang ekstrim, yaitu $\mathrm{pH}$ lebih kecil dari 5 seperti terlihat pada limbah cair Tanpa Instalasi Pengolahan Air Limbah (IPAL), apabila langsung dibuang ke badan air, maka akan terjadi perubahan dalam air sungai, seperti terganggunya aktivitas atau kehidupan ikan dan hewan air lainnya, terlarutnya beberapa mineral atau logam berbahaya tertentu, terjadinya korosif atau pengkaratan pipa-pipa besi dalam air (Fardiaz. , 1992). Menurut Palar (1994) menyatakan bahwa proses-proses kimia yang berlangsung dalam badan perairan dapat mengakibatkan terjadinya peristiwa reduksi dari senyawa-senyawa $\mathrm{Cr}(\mathrm{VI})$ menjadi $\mathrm{Cr}$ (III)dapat berlangsung bila badan perairan berada dalam kondisi asam dan untuk perairan yang bersifat basa, ion-ion Cr (III) akan diendapkan di dasar perairan. Menurut Baku Mutu Limbah Cair Provinsi DIY No 7 Tahun 2010 pH limbah cair Tanpa Instalasi Pengolahan Air Limbah (IPAL) tidak dapat dibuang langsung ke badan perairan. 


\section{BOD (Biological Oxygen Demand).}

BOD yaitu kebutuhan oksigen untuk oksidasi biologis merupakan jumlah oksigen yang dikonsumsi atau dibutuhkan oleh mikrobiologi dalam proses dekomposisi bahan-bahan organik yang membutuhkan oksigen terlarut dalam air untuk merombak bahan organik menjadi senyawa yang lebih sederhana. Nilai BOD menunjukkan oksigen terlarut yang dibutuhkan hidup mikroorganisme untuk memecahkan atau mengoksidasi bahan organik dalam air. Nilai BOD tidak menunjukkan bahan organik sebenarnya dalam air yang umum digunakan sebagai indikator pencemaran sungai yang secara tidak langsung menggambarkan bahan organik dalam badan air (Davis dan Masten, 2004). Besarnya nilai BOD menyatakan jumlah kandungan zat organik dalam air limbah, makin banyak jumlah zat organik yang dapat dioksidasi dalam air limbah, maka makin tinggi nilai BOD nya. Hasil analisis BOD limbah cair tanpa IPAL maupun dengan IPAL pada Tabel 1 dan Tabel 2 terlihat BOD tanpa Instalasi Pengolahan Air Limbah (IPAL) sebesar 1200,1 mg/1 dan BOD dengan Instalasi Pengolahan Air Limbah (IPAL) sebesar $128 \mathrm{mg} / \mathrm{l}$. Hal ini dihubungkan dengan Baku Mutu Limbah Cair Provinsi DIY No 7 Tahun 2010 keduanya tidak memenuhi baku mutu, berarti limbah cair tanpa Instalasi Pengolahan Air Limbah (IPAL) maupun limbah cair dengan Instalasi Pengolahan Air Limbah (IPAL) tidak layak untuk dibuang langsung kesungai karena akan menyebabkan pencemaran pada badan air.

\section{COD (Chemical Oxygen Demand)}

Chemical Oxygen Demand (COD) atau kebutuhan oksigen kimia adalah jumlah oksigen yang diperlukan agar bahan buangan organik yang ada di dalam air dapat teroksidasi melalui reaksi kimia. COD dapat digunakan untuk mengukur bahan organik dari limbah domestik maupun industri, reaksi kimia yang terjadi adalah bahan organik akan dioksidasi oleh kalium bikromat menghasilkan gas $\mathrm{CO}_{2}$ dan $\mathrm{H}_{2} \mathrm{O}$ serta sejumlah ion $\mathrm{Cr}$ (III) (Sawyer et al, 2003). Uji COD hanya memerlukan waktu sekitar 3 jam, sedangkan BOD memerlukan waktu 5 hari. Berdasarkan Tabel 1 dan Tabel 2 diatas bahwa hasil analisis menunjukkan COD limbah cair tanpa IPAL sebesar 3900 mg/l dan COD dengan IPAL sebesar 114,608 mg/l. Jika dibandingkan dengan Baku Mutu Limbah cair Provinsi DIY No 7 Tahun 2010 baik nilai limbah cair tanpa Instalasi Pengolahan Air Limbah (IPAL) maupun limbah cair dengan Instalasi Pengolahan Air Limbah (IPAL) telah melampaui ambang batas dan tidak memenuhi baku mutu, Hal ini tidak layak untuk dibuang langsung ke badan perairan karena akan menambah pencemaran pada badan air.

\section{$\mathrm{Cr}$ (total)}

Kromium (Cr) adalah salah satu logam berat yang cukup luas penggunaannya dalam industri penyamakan kulit. Limbah cair krom berasal dari proses penyamakan kulit, mempunyai sifat yang berbedabeda, tergantung dari besarnya krom yang digunakan pada tahapan-tahapan proses dan tidak diserap dengan sempurna oleh kulit yang diolah. Sehingga krom pada proses basah masih mengandung sisa-sisa krom dalam jumlah yang cukup besar. Seperti terlihat pada hasil analisis Tabel 1 dan Tabel 2, di mana Cr (total) pada limbah cair tanpa IPAL sebesar: $644,8500 \mathrm{mg} / 1$ dan $\mathrm{Cr}$ (total) pada limbah cair dengan Instalasi Pengolahan Air Limbah (IPAL) sebesar: 0,5 $\mathrm{mg} / \mathrm{l}$. hal ini apabila dibandingkan dengan Baku Mutu Limbah Cair Provinsi DIY No 7 Tahun 2010 baik limbah cair tanpa Instalasi Pengolahan Air Limbah (IPAL) dan limbah cair dengan Instalasi Pengolahan Air Limbah (IPAL) tidak sesuai dengan baku mutu, sehingga tidak layak untuk dibuang langsung ke badan perairan. Jadi limbah cair tersebut perlu diolah lagi untuk menurunkan $\mathrm{Cr}$ (total). 


\section{Uji Pengaruh pH dan Konsentrasi Kitosan yang Melapisi Arang Aktif TempurungKelapa terhadapJumlah $\mathrm{Cr}$ (total) Teradsorpsi}

Interaksi antara logam $\mathrm{Cr}$ (total) dengan kitosan yang melapisi arang aktif tempurung kelapa merupakan interaksi kimia melalui pembentukan ikatan kimia logam dengan gugus-gugus fungsional kitosan yang melapisi arang aktif sehingga adsorpsi logam oleh kitosan yang melapisi arang aktif dipengaruhi oleh $\mathrm{pH}$. Untuk mengetahui pengaruh $\mathrm{pH}$ terhadap adsorpsi, maka larutan $\mathrm{Cr}$ (total) diinteraksikan dengan adsorben A (K1A1), adsorben B (K2A1), dan adsorben $\mathrm{C}$ (K3A1) pada beberapa variasi $\mathrm{pH}$ yaitu $\mathrm{pH} 1,2,3,4,5,6$, dan $\mathrm{pH}$ 7. Variasi $\mathrm{pH}$ pada adsorpsi $\mathrm{Cr}$ (total) dalam larutan merupakan faktor yang berpengaruh pada adsorpsi $\mathrm{Cr}$ (total) oleh Kitosan yang melapisi arang aktif. Hal ini sesuai dengan hasil uji statistik Oneway. Variabel Cr (total) signifikan pada 0,05 ( $\mathrm{p}<0,05)$, maka variasi $\mathrm{pH}$ berpengaruh terhadap penurunan $\mathrm{Cr}$ (total) limbah cair industri penyamakan kulit. Adanya perbedaan penurunan $\mathrm{Cr}$ (total) dapat dilihat pada Gambar 1. Terlihat bahwa adsorpsi $\mathrm{Cr}$ (total) semakin meningkat pada $\mathrm{pH} 4$ sampai 5. Hal ini disebabkan pada $\mathrm{pH}$ 4 dan $\mathrm{pH} 5$ jumlah ion $\mathrm{H}^{+}$dalam larutan semakin berkurang sehingga adsorpsi $\mathrm{Cr}$ (total) lebih mudah terjadi dan $\mathrm{Cr}$ (total) yang teradsorpsi semakin meningkat jumlahnya. Adsorpsi Cr (total) oleh kitosan yang melapisi arang aktif terlihat bahwa pada $\mathrm{pH} 4$ jumlah $\mathrm{Cr}$ (total) yang teradsorpsi cenderung naik dari 87,8,\%; 90,6\%; 91,9\% (adsorben A, adsorben B, dan Adsorben C). Sesuai dengan penelitian Nomanbhay dan Palanisamy, 2005 menyatakan bahwa $\mathrm{pH}$ optimum adalah $\mathrm{pH} 4$ untuk adsorpsi $\mathrm{Cr}(\mathrm{VI})$. Pada adsorben A (K1A1) adsorpsi $\mathrm{Cr}$ (total) lebih kecil dibandingkan dengan adsorben B (K2A1) dan adsorben C (K3A1). Hal ini disebabkan pada adsorben B dan adsorben $\mathrm{C}$ kitosan yang melapisi arang aktif lebih banyak sehingga lebih banyak mengadsorpsi $\mathrm{Cr}$ (total) dan juga disebabkan karena peran arang aktif tempurung kelapa yang menyerap apa saja yang berinteraksi dengan arang aktif menyebabkan ion logam berat ( $\mathrm{Cr}$ total) ditarik oleh karbon aktif dan melekat pada permukaan arang aktif dalam kombinasi dari daya fisik kompleks dan reaksi kimia. Jadi gugus-gugus aktif yang dapat mengikat ion logam $\mathrm{Cr}$ (total) tidak hanya berasal dari situs-situs aktif pada kitosan saja, tetapi juga dari arang aktif tempurung kelapa. Hasil analisis pengaruh $\mathrm{pH}$ dan konsentrasi kitosan yang melapisi arang aktif terhadap $\mathrm{Cr}$ (total) teradsorpsi dapat dilihat pada Gambar 1.

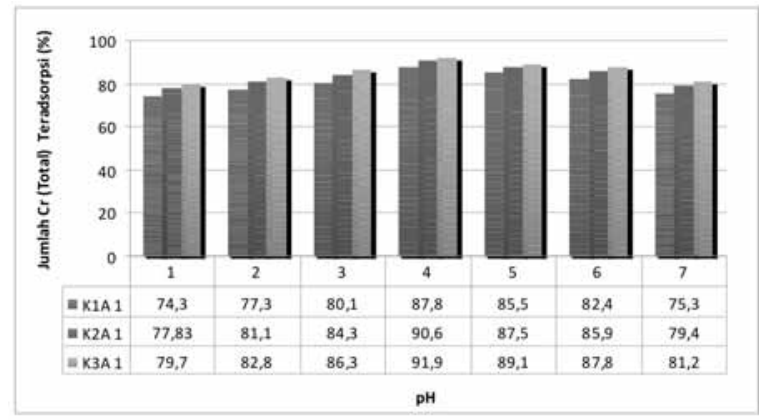

Gambar 1

Pengaruh pH dan Konsentrasi Kitosan yang Melapisi Arang Aktif terhadap Jumlah Cr (total) Teradsorpsi

\section{Pengaruh pH dan Konsentrasi Kitosan yang Melapisi Arang Aktif terhadap Jumlah BOD Teradsorpsi.}

Untuk mengetahui pengaruh $\mathrm{pH}$ terhadap jumlah adsorpsi oleh kitosan yang melapisi arang aktif tempurung kelapa, maka sampel limbah penyamakan kulit yang mengandung bahan organik maupun anorganik diinteraksikan dengan adsorben $\mathrm{A}$, adsorben $\mathrm{B}$, dan adsorben $\mathrm{C}$ pada beberapa variasi $\mathrm{pH}$ yaitu $\mathrm{pH} 1,2,3$, 4, 5, 6, dan $\mathrm{pH}$ 7. Variasi $\mathrm{pH}$ pada adsorpsi BOD dalam larutan merupakan faktor yang berpengaruh pada adsorpsi BOD oleh kitosan yang melapisi arang aktif tempurung kelapa. Hal ini sesuai dengan hasil uji statistik Oneway Anova. Variabel BOD 
signifikan pada $0,05(\mathrm{p}<0,05)$ maka variasi $\mathrm{pH}$ berpengaruh terhadap penurunan BOD limbah cair industri penyamakan kulit. Hasil analisis BOD yang teradsorpsi disajikan pada Gambar 2. Terlihat bahwa pada $\mathrm{pH} 5$ dan $\mathrm{pH}$ 6 terjadi peningkatan efisiensi penurunan BOD, dimana BOD yang teradsorpsi semakin tinggi sebesar 99,3\%; 99,4\% dan 99,5\% (adsorben A, adsorben B, dan adsorben C). Peningkatan adsorpsi BOD oleh kitosan yang melapisi arang aktif tempurung kelapa disebabkan kitosan dengan Derajat Deasetilasi yang tinggi dan memiliki gugus amino sehingga bersifat polikationik yang mempunyai kemampuan untuk mengikat logam, protein, dan zat warna (Zakaria et al, 2002), menurut Marganof, 2003 kitosan dapat dijadikan sebagai koagulan dalam proses penanganan limbah cair baik organik maupun anorganik dan juga karena adanya arang aktif tempurung kelapa sebagai substrat menempelnya kitosan yang mempunyai daya serap yang tinggi dan memiliki luas permukaan yang besar (Hadi., 2011). Oleh karena itu, adsorpsi BOD oleh kitosan yang melapisi arang aktif tempurung kelapa menjadi lebih efektif sebagai adsorben karena kombinasi kitosan dengan arang aktif tempurung kelapa.

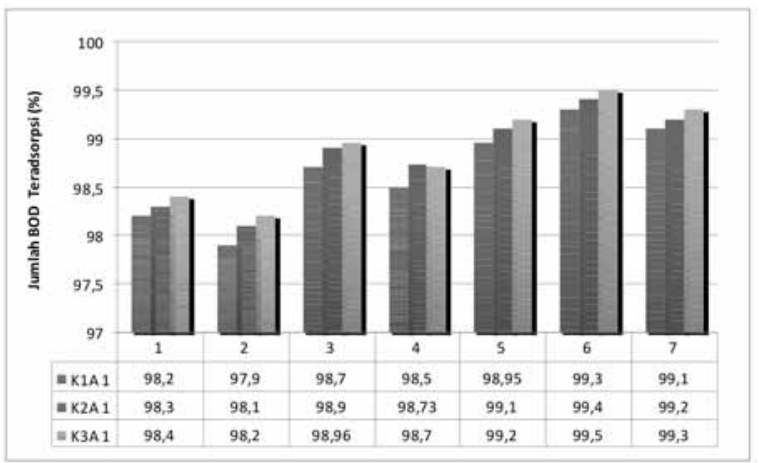

Gambar2

Pengaruh pH dan Konsentrasi Kitosan Arang Aktif TempurungKelapa terhadap Jumlah BOD Teradsorpsi

\section{Pengaruh pH dan Konsentrasi Kitosan Melapisi Arang Aktif Tempurung Kelapa terhadap Jumlah COD Teradsorpsi.}

Untuk mengetahui pengaruh $\mathrm{pH}$ terhadap jumlah adsorpsi COD oleh kitosan yang melapisi arang aktif tempurung kelapa, maka sampel limbah cair penyamakan kulit yang mengandung bahan organik maupun anorganik diinteraksikan dengan adsorben $\mathrm{A}$, adsorben $\mathrm{B}$, dan adsorben $\mathrm{C}$ dengan beberapa variasi $\mathrm{pH}$, yaitu $\mathrm{pH}$ 1, 2, 3, 4, 5, 6, dan $\mathrm{pH} 7$. Variasi $\mathrm{pH}$ pada adsorpsi COD dalam larutan merupakan faktor yang berpengaruh pada adsorpsi COD. Hal ini sesuai dengan hasil uji statistik Oneway Anova. Variabel COD signifikan pada $0,05(\mathrm{p}<0,05)$, maka variasi $\mathrm{pH}$ berpengaruh terhadap penurunan COD limbah cair industri penyamakan kulit. Hasil analisis COD teradsorpsi pada kitosan yang melapisi arang aktif tempurung kelapa dapat dilihat pada Gambar 3. Terlihat bahwa pada $\mathrm{pH} 1$ terjadi peningkatan efisiensi penurunan COD, di mana COD yang teradsorpsi lebih besar dibandingkan dengan $\mathrm{pH}$ yang lain. Hal ini disebabkan adanya bahan kimia yang tahan terhadap oksidasi biokimia, tetapi tidak tahan terhadap oksidasi kimia. Seperti yang dikemukakan oleh Fardiaz, 1992 bahwa uji COD pada dasarnyamenghasilkan nilai kebutuhan oksigen yang lebih tinggi daripada uji BOD karena adanya bahan-bahan yang stabil terhadap reaksi biokimia dapat ikut teroksidasi dalam uji COD. Pada pH 6 dan pH 7 terjadi peningkatan efisiensi penurunan, hal ini disebabkan pada $\mathrm{pH}$ yang rendah kitosan tidak optimum untuk menyerap zatzat organik karena gugus amina terprotonasi menjadi bentuk $\mathrm{NH}_{4}^{+}$sehingga kurang efektif untuk mengadsorpsi zat-zat organik yang ada pada limbah cair penyamakan kulit. Hasil analisis adsorpsi COD terhadap perbedaan konsentrasi adsorben, terlihat bahwa perbedaan konsentrasi berpengaruh pada efisiensi penurunan adsorpsi COD pada adsorben $\mathrm{A}$, adsorben $\mathrm{B}$, dan adsorben C. Hal ini disebabkan pada adsorben $\mathrm{C}$ lebih 
banyak konsentrasi kitosan dibandingkan dengan adsorben A dan adsorben B yang mempengaruhi adsorpsi COD menyebabkan kitosan yang memiliki gugus amino yang dikandungnya dan bersifat polikationik mampu mengikat protein sisa penyamakan kulit. Menurut Marganof, 2003 kitosan dapat sebagai koagulan dalam proses penanganan limbah cair baik organik maupun anorganik sehingga mempengaruhi adsorpsi COD.

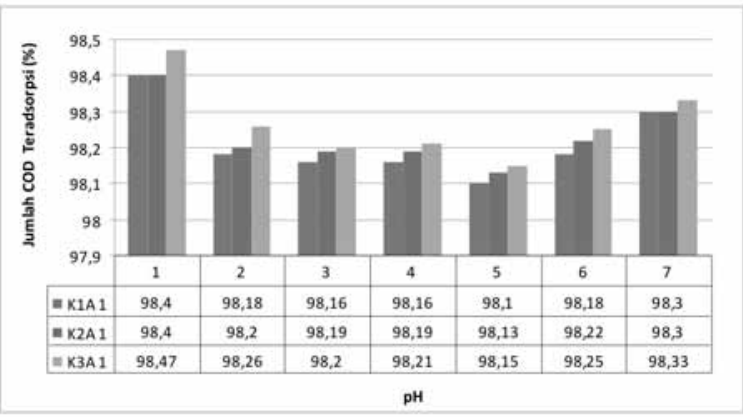

Gambar 3.

Pengaruh $\mathrm{pH}$ dan Konsentrasi Kitosan yang Melapisi Arang Aktif Tempurung Kelapa terhadap Jumlah COD Teradsorpsi

\section{SIMPULAN}

Dari hasil penelitian dan pembahasan dapat disimpulkan sebagai berikut:Pertama, karakteristik parameter kualitas limbah cair dengan IPAL maupun Tanpa IPAL melampaui Baku Mutu Limbah Cair Penyamakan Kulit Peraturan Gubernur DIY No 7 Tahun 2010. Kedua, Kitosan yang melapisi arang aktif tempurung kelapa lebih efektif menyerap logam berat $\mathrm{Cr}$ (total) pada $\mathrm{pH}$ 4, lebih efektif menyerap BOD pada $\mathrm{pH} 6$ dan lebih efektif meyerap COD pada $\mathrm{pH}$ 1. Ketiga, Sedangkan Konsentrasi kitosan yang melapisi arang aktif tempurung kelapa pada adsorben C (K3A1) lebih efektif menyerap logam $\mathrm{Cr}$ (total), BOD, dan COD dibandingkan dengan adsorben $\mathrm{A}$ (K1A1) dan adsorben B (K2A1).

\section{DAFTAR PUSTAKA}

APCC (Asian Pacific Coconut Community). , 2007. Negeri Berjuta Cocos. Trubus 469 (Desember 2008 / XXXIX): 32.
Davis, M. L and Masten, S. J. , 2004. Principles of Environmental Engineering and Science. Singapore; Mc Graw Hill Higher Education.

Effendi, H. , 2003. Telaah Kualitas Air Bagi Pengelolaan Sumber Daya Dan Lingkungan Perairan. Penerbit Kanisius Yogyakarta.

Fardiaz, S. , 1992. Polusi Air dan Udara. Diterbitkan dalam kerjasama dengan Pusat Antar Universitas Pangan dan Gizi IPB Bogor. Penerbit Kanisius Yogyakarta.

Griffon, D. J. , Sedighi, M. R. , Schaeffer, D. V. , Eurell, J. A. , and Johnson, A. L. , 2006. Chitosan scaffolds: Interconnective pore size and cartilage engineering, Acta. Biomaterialia.

Hadi, R. , 2011. Sosialisasi Teknik Pembuatan Arang Aktif Tempurung Kelapa Dengan Pembakaran Sistem Suplai Udara Terkendali. Buletin Teknik Pertanian.

Jost. P. D. T., 1990. Solid Waste Generated By Ranning Industry, Handling and Management. Pertemuan Teknis Industri Kulit. BBKKP. Yogyakarta.

Kaim W and Schwederski B., 1994. Bioinorganic Chemistry: Inorganic Elements in the Chemistry of Life, John Wiley \& Sons.

Marganof. , 2003. Potensi Limbah Udang Sebagai Penyerap Logam Berat (Timbal, Kadmium dan Tembaga) di Perairan. http://rudyct. topcities. com/pps. marganof htm.

Nomanbhay, S. M and Palanisamy, K. , 2005. Removal of Heavy Metal From Industrial Wastewater Using Chitosan Coated Oil Palm Shell Charcoal. Electronic Journal of Biotechnology, 8 (1) :48.

Ohtake, $H$ and Silver, S. , 1994. Bacterial Detoxification of Toxic Chromate In Biological Degradation and Bioreme- 
diation Of Toxic Chemical, Firth edition, Chapman and Hall, London.

Onar, N and Sarisik, M. , 2002. Using and Properties Biofibers Based on Chitin and Chitosan On Medical Application. Textile Engineering Department, Turkey.

Palar, H. , 1994. Pencemaran dan Toksikologi Logam Berat, Rineka Cipta, Jakarta.

Palar, H. , 2008. Pencemaran dan Toksikologi Logam Berat, Rineka Cipta, Jakarta.

Rodriguez. , Reinoso, F. , 1998. The Role Of Carbon Materials In Heterogeneous Catalysis. Carbon. Volume 36, No 3.
Sawyer, C. N. , McCarty, P. L., and Parkin, G. F. , 2003. Chemistry for Environmental Engineering and Science. Fifth ed. New York: Mc. Graw Hill.

Zakaria, M. B. , M. J. Jais., Wan-Yaacob Ahmad., Mohd Rafidi Othman dan Z. A. Harahap. , 2002. Penurunan Kekeruhan Efluen Industri Minyak Sawit (EIMS) Oleh Koagulan Konvensional Dan Kitosan. Prosiding Seminar Bersama UKM-ITB ke-5. Universitas Kebangsaan Malaysia. Malaysia. 